\title{
Effects of feeding whey protein on growth rate and mucosal IgA induction in Japanese Black calves
}

\section{$\operatorname{AUTHOR}(\mathrm{S}):$}

Yasumatsuya, Keiko; Kasai, Koji; Yamanaka, Kengo; Sakase, Mitsuhiro; Nishino, Osamu; Akaike, Masaru; Mandokoro, Koki; Nagase, Tatsuo; Kume, Shinichi

\section{CITATION:}

Yasumatsuya, Keiko ...[et al]. Effects of feeding whey protein on growth rate and mucosal IgA induction in Japanese Black calves. Livestock Science 2012, 143(2-3): 210-213

\section{ISSUE DATE:}

2012-02

URL:

http://hdl.handle.net/2433/153977

\section{RIGHT:}

(c) 2011 Elsevier B.V.; この論文は出版社版でありません。引用の際には 出版社版をご確認ご利用ください。; This is not the published version. Please cite only the published version. 
Mucosal IgA induction in calves

\title{
Effects of Feeding Whey Protein on Growth Rate and mucosal IgA Induction in Japanese Black Calves
}

\author{
K. Yasumatsuya ${ }^{1}$, K. Kasai ${ }^{1}$, K. Yamanaka ${ }^{2}$, M. Sakase ${ }^{3}$, O. Nishino ${ }^{4}$, M. Akaike ${ }^{4}$, \\ K. Mandokoro ${ }^{5}$, T. Nagase ${ }^{6}$ and S. Kume ${ }^{7 *}$ \\ ${ }^{1}$ Research Institute of Environment, Agriculture and Fisheries, Osaka Prefectural Government, \\ Habikino 583-0862, Japan \\ ${ }^{2}$ Shiga Prefectural Livestock Technology Promotion Center, Hino 529-1651, Japan \\ ${ }^{3}$ Northern Center of Agricultural Technology, General Technological Center of Hyogo \\ Prefecture for Agriculture, Forest and Fishery, Asago 669-5254, Japan \\ ${ }^{4}$ Nara Prefectural Livestock Technology Center, Mitsue 633-1302, Japan \\ ${ }^{5}$ The Livestock Technology Department of The Kyoto Prefectural Agriculture, Forestry \& \\ Fisheries Technology Center, Ayabe 623-0221, Japan \\ ${ }^{6}$ Chubu Shiryo Co. Ltd, Toyota 444-3213, Japan \\ ${ }^{7}$ Graduate School of Agriculture, Kyoto University, Kyoto 606-8502, Japan
}

ABSTRACT: Data from 63 Japanese Black calves were collected to clarify the effects of feeding whey protein on the growth rate and mucosal $\operatorname{IgA}$ induction in calves. Dietary treatments in milk replacers were 1) $26 \% \mathrm{CP}$ as in skim milk (control), 2) $26 \% \mathrm{CP}$ as whey

\footnotetext{
Corresponding author. Tel: $\quad+81-75-7536325$. Fax: +81-75-7536345. 

and skim milk and 3) 26\% CP as whey. Diets were offered from 3 to 63 days of age in calves. Feeding whey protein had no effects on growth rate, fecal consistency and fecal water in calves. Compared with 2 days of age, fecal IgA concentration in calves decreased at 14 days of age, while fecal water increased. Feeding whey protein increased fecal $\operatorname{IgA}$ in calves after 14 days of age, which was thought to be the increased mucosal $\operatorname{IgA}$ induction in the gut. Serum cholesterol concentration tended to be lower in calves fed whey than in control group, but feeding whey protein had no clear effects on serum glucose, NEFA, total protein and urea-N concentrations. These results suggest that feeding whey protein enhances mucosal IgA induction in calves, but feeding whey protein has little effect on growth rate and fecal consistency in calves.

Key Words: neonatal calves, mucosal IgA induction, whey, milk replacer

\section{Introduction}

Whey protein concentrate has an adequate amino acid profile than that in dried skim milk and casein, and higher proportion of whey protein concentrate in milk replacers improved calf performance when only milk replacer was fed (Lammers et al., 1998). The absorbed and retained $\mathrm{N}$ in dairy calves fed 16.1, 18.5, 22.9 and $25.8 \%$ of $\mathrm{CP}$ from whey protein sources increased linearly as dietary CP increased (Blome et al., 2003). In the previous study (Nishiyama et al., 2011b), daily gains of calves fed whey protein or skim milk at $26 \% \mathrm{CP}$ were very similar, because the appropriate supply of $\mathrm{CP}$ in the diets maintained normal growth rate of calves.

Mortality and morbidity of neonates continue to be major problems in calves, and their most common disease is diarrhea, which can cause growth retardation and death of calves. Successful neonatal health depends on many factors related to management and nutrition, but 
the improvement of the immune system is required for preventing diarrhea. Whey protein concentrate contains antiviral and immunomodulatory components, and supplemental whey protein concentrate reduces rotavirus-induced disease symptoms in suckling mice (Wolber et al., 2005) and enhances mucosal innate immunity during early life in suckling rats (Perez-Cano et al., 2007).

Passive immunity is critical to the survival and health of neonates, and colostrum or milk is a source of nutrients and immune components for neonatal calves (Blum, 2006). IgA is the most abundant Ig isotype in mucosal secretions and provides protection against microbial antigens at mucosal surfaces (Fagarasan and Honjo, 2003; Mora and von Andrian, 2009). Most IgA antibody secreting cells (ASC) express chemokine receptor CCR10, but IgA ASC from CCR10-deficient mice do not efficiently accumulate in the lactating mammary gland and lead to a significant decrease in milk IgA and fecal IgA of neonatal mice (Morteau et al. 2008). Additionally, the mucosal immune induction is also needed in neonatal calves, because the disease resistance acquired from colostrum Ig is only temporary (Quigley and Drewry, 1998). In the previous studies (Nishiyama et al., 2011a, 2011b), supplemental $\beta$-carotene with whey to maternal mice during pregnancy and lactation is useful to increase $\operatorname{IgA}$ transfer from maternal milk to neonatal mice, while supplemental $\beta$-carotene with whey may have little effect on mucosal IgA induction in neonatal mice and calves. However, supplemental whey protein has been expected to enhance mucosal $\operatorname{IgA}$ induction in neonatal calves owing to the high level of fecal IgA at 14 days of age (Nishiyama et al., 2011b).

The objective of this study was to clarify the effects of feeding whey protein on daily gains, fecal consistency and levels of fecal IgA in Japanese Black calves in order to evaluate the role of whey protein on the growth rate and mucosal IgA induction in calves. 


\section{Materials and methods}

\subsection{Experimental design}

This research was approved by the guide for the care and use of animal in Shiga Prefectural Livestock Technology Promotion Center (Hino, Japan), Northern Center of Agricultural Technology (Asago, Japan), Nara Prefectural Livestock Technology Center (Mitsue, Japan) and the Livestock Technology Center Department of The Kyoto Prefectural Agriculture, Forestry \& Fisheries Technology Center (Ayabe, Japan). Sixty three Japanese Black calves born in their centers were used, and calves consisted of 43 males and 20 females.

Dietary treatments in milk replacers were 1) commercial milk replacer which contained 26\% $\mathrm{CP}$ as in skim milk (control group, 14 males and 7 females), 2) experimental milk replacer which contained 26\% CP as whey and skim milk (whey plus skim milk group, 14 males and 7 females) and 3) experimental milk replacer which contained $26 \% \mathrm{CP}$ as whey (whey group, 15 males and 6 females). These milk replacers were provided by Chubu Shiryo Co. Ltd (Ohbu, Japan), and dietary ratio of protein source and chemical composition in milk replacers are shown in Table 1.

Calves lived with their dams after birth and received only their dam's colostrum, but colostrum $\operatorname{IgA}$ was not determined. At 3 days of age, calves were separated from their dams and housed in individual pens. From 3 to 63 days of age, calves received appropriate amounts of milk replacers and calf starter pellets to meet recommendations (Agriculture, Forestry, and Fisheries Research Council Secretariat, 2000) for TDN, protein and minerals of calves. The amounts of milk replacers offered to calves were increased from 0.5 to $0.9 \mathrm{~kg} / \mathrm{d}$ during 3 to 15 days of age, maintained at 1.0 to $1.3 \mathrm{~kg} / \mathrm{d}($ Mean $\pm \mathrm{SD}, 1.05 \pm 0.05 \mathrm{~kg} / \mathrm{d}$ ) during 16 to 50 days of age and decreased by $0.25 \mathrm{~kg} / \mathrm{d}$ during 51 to 63 days of age. Milk replacers were 
diluted with warm water at $40^{\circ} \mathrm{C}$ and offered twice a day throughout the experiment. Calf starter pellets (TDN, 75\%; CP, 20\%) were offered from 7 days of age, and the amounts of calf starter were gradually increased by 63 days of age, according to the pellet refusals of calves. Intake of milk replacers and calf starter pellets were measured every day, and their data were averaged by each week. Additionally, the calves were given free access to timothy hay from 20 days of age.

\subsection{Sample collection and analyses of serum components and fecal IgA}

Body weights of calves were measured on day $0,7,14,21,28,42,56$ and 63 after birth. Fecal consistency of calves was observed every day throughout the experiment. Fecal scores were measured on a scale of 1 to 3 ( $1=$ firm, normal; $2=$ soft, $3=$ watery), and their data were averaged by each week. Blood and fecal grab samples were collected at 13:00 hour on day 2, 14, 28, 42 and 56 after birth. Blood was sampled by a jugular vein puncture into vacuum tubes, left to stand at room temperature for 1 hour and centrifuged at 3,000 $\times \mathrm{g}$ for $15 \mathrm{~min}$. Serum glucose, total protein, nonesterified fatty acid (NEFA), triglyceride, urea $\mathrm{N}$ and cholesterol were determined by an Automatic analyzer (7600, Hitachi, Tokyo, Japan). Fecal water and fecal IgA were determined as previously described (Nishiyama et al., 2011b).

\subsection{Statistics}

Data of body weight, daily gain, feed intake, fecal score and components of serum and feces were analyzed by least squares ANOVA using the general linear model procedure of SAS (1997). The model was as follows;

$$
Y i j k=u+D_{i}+E_{j}+C_{(i j) k}+T_{1}+D_{i l}+e_{i j k l}
$$


where $u$ is the overall mean, $D_{i}$ is the effect of diet, $E_{j}$ is the effect of the experimental center, $\mathrm{C}_{(\mathrm{ij}) \mathrm{k}}$ is the random variable of calves nested in diet and experimental center, $\mathrm{T}_{1}$ is the effect of time, $\mathrm{DT}_{\mathrm{il}}$ is the interactions, and $\mathrm{e}_{\mathrm{ijk}}$ is the residuals. Data obtained from serum and feces at 14, 28, 42 and 56 days of age were used for this model. In addition, the general linear model procedure of SAS (1997) was used to analyze the effect of time on fecal content and fecal $\operatorname{IgA}$ at 2, 14, 28, 42 and 56 days of age.

An ANOVA was performed, and the differences were tested by Tukey-Kramer's multiple comparisons. Significance was declared at $P<0.05$.

\section{Results}

Body weights and daily gains of calves were not affected by treatment. Body weights increased from $31.2 \mathrm{~kg}$ at birth to $77.0 \mathrm{~kg}$ at 63 days of age, and weight gains in control group was slightly high level (Table 1). Calves were fed almost all the milk replacers, and calf starter intake was not affected by treatment. Calf starter intake increased from $41 \mathrm{~g} / \mathrm{d}$ at 2 weeks of age to $285 \mathrm{~g} / \mathrm{d}$ at 6 weeks of age and reached at $906 \mathrm{~g} / \mathrm{d}$ at 9 weeks of age.

Fecal scores of calves were almost similar in the control, whey plus skim milk and whey groups, and fecal water was not affected by treatment (Table 2). Compared with 2 days of age, fecal water increased $(P<0.001)$ at 14 days of age, while fecal $\operatorname{IgA}$ concentration decreased $(P<0.001)$ (Fig.1). Fecal IgA concentration in calves after 14 days of age was significantly higher in whey group than in control $(P<0.001)$ and whey plus skim milk $(P<0.05)$ groups. Compared with control group, fecal IgA concentration in calves fed whey plus skim milk group was slightly high level.

Serum glucose and total protein concentrations in calves were not affected by treatment (Table 3). Serum cholesterol concentration tended to be lower $(P<0.10)$ in whey group than in control group, and serum triglyceride concentration in whey group was slightly high level. 
Serum NEFA concentration at 28 days of age and serum urea-N concentration at 14 days of age were higher $(P<0.05)$ in whey plus skim milk group than in control group.

\section{Discussion}

\subsection{Effects of feeding whey protein on growth rate in calves}

Whey protein concentrate is useful for calf growth (Lammers et al., 1998; Blome et al., 2003), and the lean tissue gain of calves continued to increase with dietary CP up to $26 \%$ when calves were fed at $1.75 \%$ of BW daily (Bartlett et al., 2006). Terosky et al. (1997) reported that diets varying in the ratio of dried skim milk to whey protein concentrates at 20.6 to $21.1 \% \mathrm{CP}$ had no effects on health, growth, apparent digestibility and blood measurements including glucose, total protein, NEFA, triglyceride and urea-N in Holstein calves up to 8 weeks of age. In the previous (Nishiyama et al., 2011b) and present studies, feeding whey protein had no effects on the growth rates and serum glucose, total protein, NEFA, triglyceride and urea-N in Japanese Black calves. The lower serum cholesterol in calves fed whey protein agreed with the previous reports (Nagaoka et al., 1992; Sautier et al., 1983), which showed that serum cholesterol was lower in the rats fed whey protein and whey protein exhibited a greater hypocholesterolemic effect in comparison with casein or soybean protein.

Severe diarrhetic feces of calves contain more than $85 \%$ moisture, while feces that contain less than $80 \%$ moisture are considered as normal (Abe et al., 1999). In the present study, the average fecal water was below $80 \%$ in the 3 groups and feeding whey protein had no effects on fecal consistency and fecal water in calves. These results indicate that feeding whey protein at 26\% CP may have little effect on the growth rate and fecal consistency in calves. 
The increased IgA transfer from maternal milk to neonates is important for maintaining normal calf health, because $\operatorname{Ig} \mathrm{A}$ antibodies are specific for antigens of the intestinal microflora and act to limit penetration of commensal intestinal bacteria through the neonatal intestinal epithelium (Harris et al., 2006; Roux et al., 1977). Fecal IgA in calves at 2 days of age was relatively high level, but varied from 0.004 to $59.3 \mathrm{mg} / \mathrm{g}$ in the present study. The lower fecal IgA may be inappropriate for newborn calves, but their values of fecal water were almost below $80 \%$.

The gut-associated lymphoid tissue is the largest immunologic tissue in the body, and the mucosal immune induction of the newborn gastrointestinal tract is dependent on an active process of IgA ASC accumulation in the gut (Nishiyama et al., 2011a). IgA antibodies produced from IgA ASC in the guts are secreted mainly as dimmers after incorporation of the $\mathrm{J}$ chain and association with a transmembrane epithelial glycoprotein known as polymeric-Ig receptor (Fagarasan and Honjo, 2003). In the present study, feeding whey protein increased fecal IgA in calves after 14 days of age, which was thought to be the increased mucosal IgA induction in the gut. In addition, compared with the skim milk feeding, fecal IgA in calves fed whey plus skim milk was slightly high level after 14 days of age.

Whey protein concentrate promoted the expansion of cell subsets involved in innate and mucosal immune response in suckling rats (Perez-Cano et al., 2007). The globulin fraction of whey was shown to contain a nondialyzable factor that is chemotactic for IgA-positive lymphocytes (Czinn and Lamm, 1986). In addition, the beta-lactoglobulin in whey protein has more resistance to pepsin degradation than casein, and the undigested beta-lactoglobulin activates IgA production (Takasugi et al., 2001; Wong et al., 1998). These results suggest that feeding whey protein is useful to enhance mucosal IgA induction in calves, and this effect 
may be partly due to the globulin-mediated activation on IgA ASC accumulation in the gut. However, further studies are needed to evaluate the role of whey protein on the immune system in neonatal calves.

\section{Acknowledgments}

The present study was supported by the project of Ministry of Agriculture, Forestry and Fisheries (Tokyo, Japan).

\section{References}

Abe,M., Matsunaga,M., T.Iriki, Funaba,M., Honjo,T., Wada,Y. 1999. Water balance and fecal moisture content in suckling calves as influenced by free access to dry feed. J.Dairy Sci. 82, 320-332.

Agriculture, Forestry, and Fisheries Research Council Secretariat (AFFRCS). 2000. Japanese Feeding Standard for Beef Cattle. Chuouchikusankai, Tokyo, Japan.

Bartlett, K.S., McKeith, F. K., VandeHaar, M. J., Dahl , G. E. and Drackley J. K. 2006. Growth and body composition of dairy calves fed milk replacers containing different amounts of protein at two feeding rates. J. Anim. Sci. 84,1454-1467.

Blome, R.M., Drackley, J.K., McKeith, F.K., Hutjens, M.F., McCoy, G.C. 2003. Growth, nutrient utilization, and body composition of dairy calves fed milk replacers containing different amounts of protein. J. Anim. Sci. 81, 1641-1655.

Blum, J,W. 2006. Nutritional physiology of neonatal calves. J. Anim. Physiol. Anim. Nutr. 90, $1-11$ 
Czinn, S.J., Lamm, M.E. 1986. Selective chemotaxis of subsets of B lymphocytes from gut-associated lymphoid tissue and its implications for the recruitment of mucosal plasma cells. J. Immunol. 136, 3607-3611.

Fagarasan, S., Honjo, T. 2003. Intestinal IgA synthesis: regulation of front-line body defenses. Nature Rev. Immunol. 3, 63-72.

Harris, N.L., Spoerri, I., Schopfer, J.F., Nembrini, C., Merky, P., Massacand, J., Urban, J.F. Jr, Lamarre, A., Burki, K., Odermatt, B., Zinkernagel, R.M., Macpherson, A.J. 2006. Mechanisms of neonatal mucosal antibody protection. J. Immunol. 177, 6256-6262.

Lammers, B.P., Heinrichs, A.J., Aydin, A. 1998. The effect of whey protein concentrate or dried skim milk in milk replacer on calf performance and blood metabolites. J. Dairy Sci. 81, 1940-1945.

Mora, J.R, von Andrian, U.H. 2009. Role of retinoic acid in the imprinting of gut-homing IgA-secreting cells. Semin. Immunol. 21, 28-35

Morteau, O., Gerard, G., Lu, O., Ghiran, S., Rits, M., Fujiwara, Y., Law, Y., Distelhorst, E.M., Nielsen, E.M., Hill, E.D., Kwan, R., Lazarus, N.H., Butcher, E.C., Wilson, E. 2008. An indispensable role for the chemokine receptor CCR10 in IgA antibody-secreting cell accumulation. J. Immunol. 181, 6309-6315.

Nagaoka, S., Kanamaru, Y., Kuzuya, Y., Kojima, T., Kuwata, T. 1992. Comparative studies on the serum cholesterol lowerimg action of whey protein and soybean protein in rats. Biosci. Biothech. Biochem. 56, 1484-1485.

Nishiyama, Y., Sugimoto, M., Ikeda, S., Kume, S. 2011a. Supplemental $\beta$-carotene increases IgA secreting cells in mammary gland and IgA transfer from milk to neonatal mice. Brit. J. Nutr. 105, 24-30.

Nishiyama, Y., Yasumatsuya, K., Kasai, K., Sakase, M., Nishino, O., Akaike, M., Nagase, T., Sugimoto, M., Ikeda, S., Kume, S. 2011b. Effects of supplemental $\beta$-carotene with whey 
on IgA transfer from maternal milk and mucosal $\operatorname{Ig} \mathrm{A}$ induction in neonatal mice and calves. Livest. Sci. 135, 95-100.

Perez-Cano, F.J., Marin-Gallen, S., Castell, M., Rodriguez-Palmero, M., Rivero, M., Franch, of murine spleen cells by materials associated with bovine milk protein fractions. J Dairy 
Sci. 81, 1825-1832. 
Figure 1. Fecal water content and fecal $\operatorname{IgA}$ concentration (Mean $\pm \mathrm{SE}$ ) of calves in control and 56 days of age.

276 

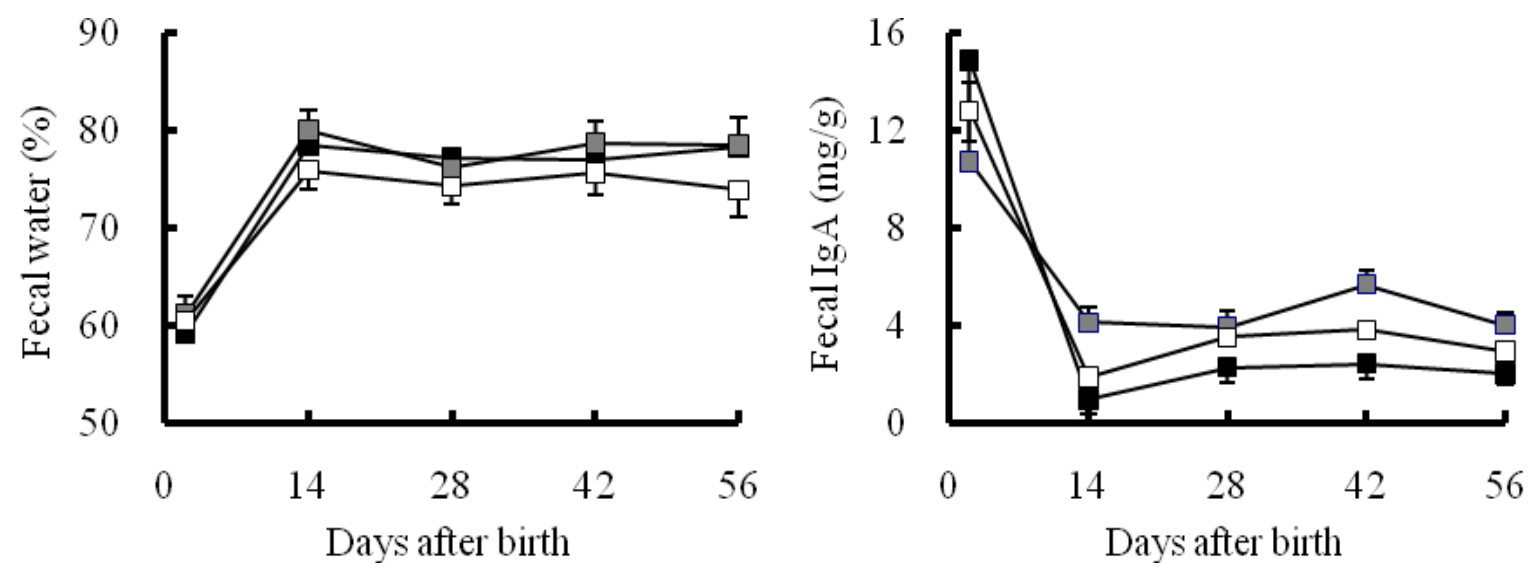

$281 \quad$ Figure 1. 


\section{Table 1}

Dietary ratio of protein source and chemical composition in milk replacers for control, whey plus skim milk (WS) and whey groups in calves.

\begin{tabular}{lrrr}
\hline & Control & WS & Whey \\
\hline Ingredient (\%) & & & \\
Skim milk & 66.3 & 28.5 & 0 \\
Dried whey & 3.1 & 2.8 & 17.5 \\
Whey protein concentrate & 7.4 & 45.0 & 56.5 \\
$\quad$ Soybean protein concentrate & 2.0 & 2.0 & 0 \\
Composition (as-fed basis) & & & \\
CP, \% & 26.3 & 26.4 & 26.1 \\
Crude fat, \% & 17.2 & 17.3 & 17.3 \\
\hline
\end{tabular}




\section{Table 2}

Daily gain, calf starter intake, fecal score and fecal components for control, whey plus skim milk (WS) and whey groups in calves

\begin{tabular}{|c|c|c|c|c|c|c|c|}
\hline & \multirow[b]{2}{*}{ Control } & \multirow[b]{2}{*}{ WC } & \multirow[b]{2}{*}{ Whey } & \multirow[b]{2}{*}{ SE } & \multicolumn{2}{|l|}{$P$} & \multirow[b]{2}{*}{ Diet $\times$ Time } \\
\hline & & & & & Diet & Time & \\
\hline Daily gain, kg/d & 0.771 & 0.734 & 0.722 & 0.022 & NS & $* * *$ & NS \\
\hline Starter intake, g/d & 304 & 217 & 263 & 31 & NS & $* * *$ & NS \\
\hline Fecal score & 1.31 & 1.36 & 1.35 & 0.04 & NS & $* * *$ & NS \\
\hline Fecal water ${ }^{1}, \%$ & 77.5 & 75.3 & 78.1 & 2.2 & NS & NS & NS \\
\hline Fecal $\operatorname{IgA}^{1}, \mathrm{mg} / \mathrm{g}$ & $1.86^{\mathrm{B}}$ & $2.91^{\mathrm{b}}$ & $4.67^{\mathrm{A}, \mathrm{a}}$ & 0.45 & $* * *$ & $* *$ & NS \\
\hline
\end{tabular}


291

\section{Table 3}

Serum components for control, whey plus skim milk (WC) and whey groups in calves at 14,28,42 and 56 days of age

\begin{tabular}{|c|c|c|c|c|c|c|c|}
\hline & \multirow[b]{2}{*}{ Control } & \multirow[b]{2}{*}{ WC } & \multirow[b]{2}{*}{ Whey } & \multirow[b]{2}{*}{ SE } & \multicolumn{2}{|l|}{$P$} & \multirow[b]{2}{*}{ Diet $\times$ Time } \\
\hline & & & & & Diet & Time & \\
\hline Glucose, $\mathrm{mg} / \mathrm{dl}$ & 107.0 & 110.6 & 102.0 & 2.4 & NS & NS & NS \\
\hline Cholesterol, mg/dl & $112.1^{\mathrm{a}}$ & $103.5^{\mathrm{ab}}$ & $90.7^{\mathrm{b}}$ & 6.5 & $* *$ & $* * *$ & NS \\
\hline NEFA, $\mu \mathrm{Eq} / 1$ & 268.7 & 309.9 & 280.6 & 23.0 & NS & NS & $*$ \\
\hline Triglyceride, mg/dl & 14.4 & 14.8 & 17.1 & 1.0 & $*$ & NS & NS \\
\hline Total protein, g/dl & 5.5 & 5.6 & 5.5 & 0.1 & NS & $* * *$ & NS \\
\hline Urea-N, mg/dl & 11.0 & 11.5 & 11.6 & 0.4 & NS & $* *$ & $*$ \\
\hline
\end{tabular}

